\title{
Islamic Education in The Inclusive School: Experimental Study of The A pplication of Differentiated Instruction For Slow Learners
}

DOI 10.18196/AIIJIS.2019.0106.281-301

\section{ANITA AISAH, DWI SANTOSA AB.}

Faculty of Islamic Studies Universitas Muhammadiyah Yogyakarta

Email: anita.aisah@ umy.ac.id

\section{ABSTRACT}

0 ne of competences that teachers need to achieve is readiness to teach students with various characteristics. Teachers of I slam religion subject in some schools do not have adequate competence to teach diverse students. Slow learners are mostly found in both regular and inclusive schools. The researchers offer a method which can adjust a curriculum to be compatible to students' conditions namely differentiated instruction method (DI) to be applied in I slam religion subject. The goal of this research serves to figure out whether or not DI method can improve learning motivation and achievement for slow learners. The research respondents are three slow learners in inclusive schools. It applied pretest-posttest experiment research method. The research was conducted in A pril and $M$ ay, 2019 in Primary School XX in Bantul regency. D ata were collected using observation technique, pretest in the form of knowledge test covering previous theme namely sholat (praying) and posttest in the form of the result of knowledge test. Finding revealed that two out of three slow learners did not attend complete experiment process so that there was only one student left. There was a significant increase on knowledge score between pretest and posttest (sig 0,000). This student's learning motivation improved as well from someone who was previously crying when being asked to come to the front of the class or to answer questions becoming a student who was more communicative.

K eywords: Slow learner, D ifferentiated Instruction, Islamic Religious Education, Inclusive School,

\section{ABSTRAK}

Salah satu kompetensi guru adalah siap mengajar pada variasi siswa. G uru PAI di beberapa sekolah tidak memiliki bekal yang cukup untuk men gajar siswa yang beragaam. 
Siswa slow learner paling banyak ditemui di sekolah reguler maupun sekolah inklusi. Peneliti menawarkan metode yang menyesuaikan dengan kondisi siswa yaitu metode D ifferentiated Instruction atau DI untuk diterapkan pada mata pelajaran PA I. Tujuan penelitian ini adalah untuk mengetahui apakah metode D I dapat meningkatkan motivasi dan prestasi belajar bagi siswa slow learner. Responden pada penelitian ini adalah tiga siswa slow learner di sekolah inklusi. M etode penelitian menggunakan metode eksperimen pretest-posttest. Penelitian dilakukan selama bulan M ei sampai A pril 2019 di Sekolah Dasar N egeri $X X$ di $K$ abupaten Bantul. M etode pengambilan data menggunakan observasi, Pretest berupa tes pengetahuan pada tema sebelumnya yaitu sholat dan posttest berupa hasil tes pengetahuank. H asil dari penelitian ini adalah ada dua dari tiga siswa slow learner yang tidak mengikuti proses eksperimen secara penuh, sehingga hanya ada satu responden penelitian. Skor pengetahuan terjadi peningkatan secara signifikasi antar pretest dan posttest (Sig 0,000). M otivasi belajar siswa ini mengalami peningkatan dari sebelumnya yang menangis ketika diberikan tugas menjawab pertanyaan, sekarang menjadi lebih komunikatif.

K ata K unci: Slow learner, Differentiated Instruction, Pendidikan A gama Islam, Inclusive School

\section{INTRODUCTION}

The topic of religious education in Islamic teaching has been laid out in the Surah (chapter) 'Abasa. In this chapter, it is cited that individuals with the special needs deserve a decent education. In 1984, the world started to recognize education for diversity through the declaration of human rights by United Nation assembly. After the declaration, a number of countries began to declare education for all one of which was Thailand in 1990. Indonesia government officially started implementing diversity education or known as inclusive education in 1993 through standard regulation about equality for the disabled. In 2004 in Bandung, Indonesia legally declared a program towards inclusive education. The declaration of "Indonesia towards Inclusive Education" aimed at encouraging all schools to prepare education for all including for children with special needs. The concept of education for all or know $n$ as inclusive education is implemented in Indonesia through a policy stating that each school has to accept students with a variety of conditions.

Education agency in Yogyakarta has pointed out some schools to be inclusive schools. Other schools which have not officially announced as inclusive schools do not have the right to refuse students with special needs who wish to study there. Inclusive schools should not only serve as a label; instead they should gain support from all human resources and 
facilities in the respected schools. One of human resources which seems to be not ready yet is the teachers' class management skills in inclusive education setting.

This research focuses on one subject taught in each inclusive school namely "Pendidikan Agama Islam" or Islamic Education Subject. This subject is a field delivering religious materials, developing positive attitude, Islamic trait, and students' skills in actualizing religious teaching. Islam religion subject serves seven crucial functions in building students' character. In 2013 curriculum, Islam religion subject is integrated with manner education. Islamic education subject and manner education are taught for four hours per week in primary schools and three hours in secondary schools. Number of meeting and duration of each meeting will be higher and longer in schools under Islamic institution. Each student deserves Islam religion education. According to Syarifudin, et al. ${ }^{1}$ Islam religion subject is one of essential educations since through this education the national education goal will be accomplished. One of national education goals is equipping students with strong faith in god ${ }^{2}$.

Pilot studies have been carried out by the researchers in 2011 and 2016-2018. In 2011, the researchers were conducting profession practice handling eight problematic students in four levels of school. Researchers completed interview, observation, and psychodiagnostics assessment. The finding showed that four out of eight students were diagnosed with cognitive impairment or slow learner. Some practicing students from UGM majoring in Psychology revealed the same finding; slow learners studied at regular schools.

The next pilot study was conducted by researchers through interview and observation while supervising students of Islam religion education program in school-based field study (Praktek Pengalaman Lapangan/ PPL) both in primary schools and senior high schools in Yogyakarta between 2016-2018. Findings of pilot study indicated that teachers did not conduct a detail assessment on students' psychological state, evaluation was completed in classic manner, and various learning methods existed from lecturing up to role-play. Several teachers utilized PowerPoint media in delivering learning material or playing videos. The practicing students discovered some students with indicators of students with special needs such as low learning motivation, under average scores, concentration impairment in the classroom causing them to be passive, and problematic social 
behavior. In the schools where students did their school-based field study, there were no supervisor teachers. Basically, the schools did not know how to assess both students with special needs and normal students. Based on an interview, three Islam religion subject teachers in three schools admitted that some of their students showed the characteristics of slow learners.

Types of students' diversity in classroom can be viewed from a number of aspects. However, the most frequently happening impairment in class is cognitive impairment. This idea is supported by Aisah ${ }^{3}$, an inclusion expert, who states that students' most frequent diversity is from intellectual intelligence aspect. Learners' diversities of this aspect consist of some categories namely genius students, above-average students, average students, under-average students or slow learners, and mentally retarded students ${ }^{4}$.

Based on data reported by Indonesia Social M inistry (Kemenkes RI), it showed that in 2011, students with special needs in Indonesia reached 7 million or around $3 \%$ of total Indonesian citizens. Out of those 7 million, most of them were signified to have characteristics of slow learners, autism, and other intellectual disabilities (Indonesia Health M inistry, 2014). Amelia conducted a research addressing types and characteristics of slow learners. It turns out that most slow learner subjects possess the same characteristics. Those traits are low understanding ability, slow academic task accomplishment, low learning achievement, and a grade failing ${ }^{5}$

The learning process of Islam religion subject for slow learners in schools where the pilot studies were completed can be concluded that its process applies concept of 'students adjust themselves with the curriculum'. Teachers did not modify curriculum in more detail to meet students' needs. Basically, teachers did not have the capability to assess students. There were a lot of students indicated with special needs, but teachers did not know how to diagnose and make intervention in class.

The findings of researchers' initial research are supported by some other studies. A study was carried out by Pramuji ${ }^{6}$ in Purwokerto. Pramuji found out that learning process of students with special needs was conducted in classical manner applying the same curriculum although companion teachers existed there. It caused by the fact that there was only one Islam religion subject teacher and he was not capable of modifying the curriculum. Referring to research finding by Hanum ${ }^{7}$ regarding method in learn- 
ing Islam religion in a special school Kota Langsa, it was mentioned that Islam religion subject teacher had not played his role optimally in teaching students with special needs. Besides, he was lack of knowledge about methods in teaching Islam religion subject for students with special needs. The teacher still applied classical teaching. Grounded from observation by Hanum $^{8}$, many students seemed to be passive during Islam religion learning process in the classroom. Hanum suggested the necessity of training to teach a variety of students.

In 2019, Nugrahayati and M ustadi did a research about the learning process of slow learners. It resulted in similarities of learning process between regular students and slow learners. It was viewed from aspects of planning, implementation, evaluation, and follow-up. There was no specific lesson plan for slow learners. Common lesson plan components for slow learners cover method, media, and evaluation which were also used for other students. One of special treatments for slow learners was additional time to complete assignment after school ${ }^{9}$.

In an effective classroom, an educator consistently pays attention to four elements namely students, learning environment, learning content, and the way they teach or called as instruction ${ }^{10}$. In inclusive education, there are various students in each class including students with special needs. Teachers should have methods for various classes. Teaching Islam religion to slow learners requires specific skills. If those students exist in inclusive class, teachers need to modify the curriculum so that the instructional process can be adapted to students' condition. Curriculum modification has been proven to be successful at improving active behavior of those students with cognitive impairment to participate in classroom learning ${ }^{11}$. One of suggested methods is differentiated instruction (DI). DI contains aspects of students' condition, teaching environment, and teaching method. The main purpose is ensuring that teachers focus on process and procedures for learning effectiveness within students' various conditions ${ }^{12}$.

Started being developed in Romania as an attempt to educate students with special needs ${ }^{13}$, differentiated instruction (DI) is an appropriate method to be applied in classrooms with various students. One of DI phases is psychological assessment on students' cognitive ability and learning styles. Students who do not undergo such assessment will be risked of getting negative label or stimulating stigma for both smart and less smart students. George ${ }^{14}$ exposes several reasons on the significance of 
implementing DI in inclusive class. Differentiated instruction method is going to raise teachers' awareness on individual differences in the classroom so that students will grow and undergo self-development in inclusive class. Students are offered great chance for fairness in talent development when learning in inclusive class. DI method is applicable for all students' types including those with above-average intelligence or gifted students. Teachers who implement DI will pay more attention to planning phase as gifted students are expected to be able to accomplish the learning assignment excellently, persistently, and easily with good grades.

The researchers formulate research question as the following: How is differentiated instruction implemented in Islam religion subject learning context for slow learners? How do learning behavior and achievement change before and after differentiated instruction method is applied to slow learners in inclusive schools?

This study aims at examining whether or not differentiated instruction is effective to be implemented in Islam religion learning process for slow learners in inclusive classes. Researchers will observe enthusiastic behavior of slow learners and take a look at daily exam score documentation during experiment process.

\section{THEORETICAL FRAMEWORK}

\section{A. Differentiated Instruction-B ased Curriculum Modifica tion}

Differentiated Instruction (DI) is a teaching and learning approach in a class setting where students have a range of abilities and this method allows them to learn in the same class. DI-based curriculum modification method is applied to enable teachers to know students better in terms of their knowledge proficiency level, learning readiness, linguistic competence, and students' interest and interaction ${ }^{15}$. The basic concept of DI is that curriculum accommodates students instead of students adapt themselves to curriculum. DI is employed so that same learning materials can be taught to all students using numerous learning strategies. It enables students with a range of knowledge levels can optimally meet learning objectives.

In implementing DI method, there are several elements which can be modified such as planning a lesson based on students' learning styles, 
grouping students based on their similar interest, theme, or task, evaluating students' learning using formative assessment, managing the classroom to be a conducive environment, conducting sustainable evaluation, and adapting learning content to meet students' needs ${ }^{16}$.

Specifically, DI responds to students' sustainable learning progress, what they already know as well as what they want to know and learn so that students who learn under DI method implementation get the learning process according to their needs ${ }^{17}$. Andini ${ }^{18}$ elaborates specific characteristics about DI covering the following ideas.

1. Differentiated learning is different from individual learning concept. During learning process, teachers often teach whole class or big group, small group, or individual. Those variations are important to do to improve students' knowledge and skills, and build a sense of togetherness.

2. Differentiated instruction is not similar to unsystematic or chaotic instruction.

Educators who implement DI will manage and maintain classes using composed activities. Differentiated instruction in the class will improve the effectiveness of students' learning achievement; not a class with no planning and discipline.

3. DI determines heterogenic and flexible grouping.

In classes which employ DI, the formed groups will have the flexibility where students with strength on particular field will join other students and cooperate with them. In DI, groups will always change referring to students' experience and learning needs.

4. DI is proactive and is based on accomplished assessment.

In DI-based classes, they hold a basic concept that students have numerous learning needs which are different from one another. Educators have to be proactive to find and arrange planning with a variety of methods to express how students can study conveniently.

Tomlinson, et al ${ }^{19}$ elaborate aspects of differentiated instruction. DI aspects are explained based on the steps in formulating DI. Basic steps in DI cover two main aspects namely teacher-based method and studentbased method ${ }^{20}$. Teacher-based method consists of content, process, and product. Content deals with what students will comprehend and what they will learn. In content aspect, teachers modify how each student learns 
a topic. For students with high readiness or independence and understanding towards learning content, it will present them more ease to be optimal during the learning process. On the other hand, for students with low readiness, educators need to create some modification and adaptation based on their readiness levels.

The second aspect is process. Process is related to how students retain information or how students learn. Process is students' activities in perceiving knowledge, understanding, and skills based on the themes that they are going to study. The third aspect on teacher-based method is product. Product refers to evidence or something that students have learnt and understood. Learners will demonstrate or apply what they have studied.

Aspects on student-based method consist of learning readiness, interest and profile. The first aspect in student-based method is student readiness. It addresses students' development level of understanding and achievement in the classroom. Students with high learning readiness will be prepared to learn, understand, and have excellent skills. Those students are certain to be successful and are able to complete given tasks. The second aspect is students' interest. Interest is the greatest students' internal factor to study. If the given learning tasks stimulate students' curiosity and learning motivation, students will allocate decent attention on learning activities which later display positive impact on achievement.

The next aspect is learning profile. Basically, learning should encourage students to do activities according to their preferences. Students' learning profile will be correlated with a number of factors like language, culture, health, family condition, and other specific elements. Learning profile deals with learning style. Some students have visual learning style (reading, seeing), some are auditory (listening to lecture or discussion), while some others are kinesthetic (movement). Beside learning style, learning profile is also linked with multiple intelligences. The concept of How ard Gardner theory of multiple intelligences fosters students to view their attitudes toward ways of learning Islam religion so that students can learn conveniently. Multiple intelligences refer to visual, verbal, logical, rhythmic/ auditory, interpersonal, intrapersonal, kinesthetic, and naturalistic intelligence.

DI implementation has to refer to steps by Tomlinson et al ${ }^{21}$. Those DI steps aim at maximizing each student's capability and achievement level 
in which teachers will provide guidance during the learning process. DI steps are explained in the following schema.

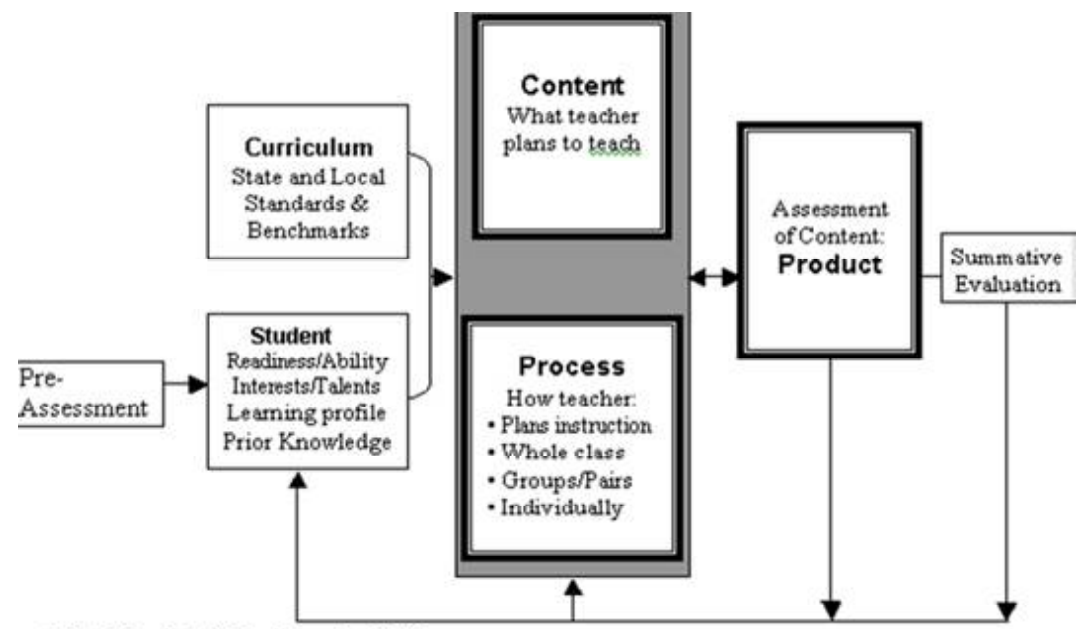

(adroted fiom Quksos, L. \& bnes, L., 2001)

The above schema explains the process of DI implementation. It begins with initial assessment. Educators carry out initial assessment through pretest to figure out each student's capability. It is expected that teachers can plan, design, and modify curriculum based on students' readiness, learning style, intelligence, and preliminary knowledge. Students' learning ability is classified into three levels one of which is independent level. Students on this level do not need any assistance and are able to complete tasks independently. The next level is instructional level. On this level, students need guidance in understanding a concept and completing tasks. The lowest level is frustration level. Students locate difficulties in keeping up with the lesson because they have not achieved full understanding on basic concepts and attain limited knowledge which cause them to easily give up and become frustrated in doing the learning tasks.

\section{B. Characteristics of Slow Learners}

Slow learner is a term used to refer to students with under-average ability to learn academic skills compared to their peers. Slow learners' ability in understanding language, number, and concepts is very limited. Capability to perceive situation or environment condition is below the average of their peers. Slow learners possess characteristics as below: 
1. Slow learners need physical assessment. It aims at figuring out their senses' ability like their hearing, sight, and speaking skills. Besides, nutrition assessment is also necessary when they are still babies.

2. Mental development of slow learners is affected by physical growth. Lack of oxygen when being born causing wound in particular brain part, bleeding from the womb, and lost opportunities to receive stimulation in particular development tasks during their lives are some examples of physical impairment.

3. Intellectual development is affected by mental development. Slow learners' intellectual state can be detected through intelligence test. The IQ scores of slow learners range from 50-89.

4. Social economic condition can give impact on students' learning progress at school. A lot of slow learners come from middle to low economy class. Research reveals that slow learners have less educated parents.

5. The characteristic of slow learners is finding it difficult to adapt themselves to the surrounding. This causes slow learners to have low selfefficacy and low confidence.

6. Slow learning behavior of slow learners is manifested by slow response in experiencing and reacting to the surrounding environment, low curiosity, being inattentive towards their academic tasks, less fluency in speaking, dependence on teachers or other students, weak memorization, difficulty in knowledge transfer, and complexity in understanding abstract concept.

\section{The $\mathbf{N}$ ature of Istamic Education}

According to an interpretation Islamic education is an activity to educate people about Islam. Islamic subject is a part of Islamic education ${ }^{22}$. This subject appears as an effort to educate people about Islam or Islamic teachings and values to be someone's way of life. Islamic education subject can be in the form of set of activities to help individual or group students to actualize Islamic values in their daily attitude and skills. It denotes to meeting between two people or more resulting in embedding Islamic teachings.

The general goal of Islam religion subject is to reach a quality mentioned in Al-Quran and hadith so that teachers of Islam religion education have the duties to guide and direct their students to be powerful 
Moslems as a reflection of their faith. The coverage of Islam education covers three fields namely aqidah, sharia, and moral. Aqidah is a field of faith in Islam addressing everything someone believes on. Sharia is Allah's rules to regulate human relationship with Allah, among human, and human with the nature. Moral is a part in Islam to control human behavior.

\section{RESEEARCH METHODE}

This research is an experiment with quantitative approach. Pretest posttest group design is the experiment method used. According to Latipun ${ }^{23}$ experiment method of pretest posttest group design is a method involving one group only namely experiment group. Pretest and posttest were given to one group before and after treatment was given. At the end of the research, comparison was accomplished to the result of observation between students' learning behavior and learning outcomes of students with special needs.

\begin{tabular}{l|l|l} 
PRETEST & TREATMENT & POSTTEST \\
\hline Pretest & $\begin{array}{l}\text { Differentiated instruction method on Islam } \\
\text { religion education subject for slow learners in } \\
\text { primary schools }\end{array}$ & Posttest \\
\hline
\end{tabular}

The site of this research was a primary school in Bawuran, Bantul. There were some students identified to have the characteristics of slow learners in the school. The research subjects were three slow learners of inclusive school.

The independent variable of this research was the implementation of differentiated instruction on Islam religion subject for slow learners. Phases in implementing DI were 1 ) researchers and teachers discussed the characteristics of slow learners; 2 ) teachers and researchers decided the topic of learning; 3) researchers conducted class observation, 4) researchers modified the curriculum; 5) experiment process was completed; 6) experiment evaluation was carried out. The dependent variable was learning achievement before and after the treatment.

Data collecting method of this research was quasi experiment method. Experiment method was applied to conduct curriculum modification method using differentiated instruction on Islam religion education. The next data collecting method was observation method. Observation was completed to see slow learners' learning behavior within DI context in the 
classroom. Observation was performed with non-participant technique by anecdotal recording model. Observation by anecdotal recording is a cumulative recording of several individual's extraordinary behavior ${ }^{24}$. Interview method was as well accomplished by researchers towards the teachers. The interview aimed at figuring out the difference of slow learners' behavior before, during, and after the experiment. Researchers employed semi-structured interview in which the interviewer has a list of topic or issue called as interview guide ${ }^{25}$.

Content validity of this research was obtained through consultation to professional judgment; in this case they are inclusion experts in Center of Inclusion Study in Tumbuh primary school and education psychologist. Professional judgement checked the module of the implementation of modified curriculum using differentiated instruction on Islam religion subject. This study employed data analysis method of non-parametric quantitative approach. Non-parametric quantitative is utilized if data distribution is not normal and the number of research subjects is really small ${ }^{26}$. Difference test used in this study was Wilcoxon test. The goal of administering this test was to examine whether or not there was a significant difference between pretest and posttest scores on Islam religion knowledge of slow learners.

\section{FINDINGS AND DISCUSSION}

In this chapter, this research is divided into three elements namely preresearch, research, and discussion.

\section{A. PreResearch}

The first session in pre-research was an initial assessment of school condition, students, and the process of learning Islam religion subject. Pre-research was conducted between $24^{\text {th }}$ up to $29^{\text {th }}$ of August, 2019 in Primary School XX in Bantul. The teacher gave a description about students' condition at the school. The teacher suggested researchers to take class IV B as the experiment class. There were 28 students in the respective class. Islam religion subject was given $2 \times 2$ learning hours each week. Researchers conducted class observation and spotted three students with slow learners' characteristics. Student A had under-average score, was hard to concentrate in the classroom, and his sight was empty. Student B was quieter, was passive during the learning process, had under-average scores, and was hard to participate in classical learning. Student $\mathrm{C}$ had 
ever failed a grade, did not desire to participate in the learning, cried when being asked to come to the front of the class, and had low ability in reading. Researchers decided those three students as the research subjects.

The second session in pre-research was training of trainer (TOT). TOT was held to teachers of Islam religion subject who would do the experiment. TOT prepared teachers' competence in implementing DI. Based on DI theory by Thomlonson et $\mathrm{al}^{27}$ teachers need to be prepared to be able to apply DI based on student-based and teacher-based method. Studentbased method prepares teachers to be capable of assessing students in the classroom regarding their learning readiness, interest, and profile. Researchers created a table accommodating the three aspects in studentbased method and teachers then filled it in according to the condition of students' diversity in the classroom. The table is presented below.

\section{Table of Student-B ased Method I mplementation}

\begin{tabular}{l|l|l|l|l} 
NO & $\begin{array}{l}\text { NAME OF } \\
\text { STUDENT }\end{array}$ & $\begin{array}{l}\text { LEARNING } \\
\text { READINESS }\end{array}$ & $\begin{array}{l}\text { INTEREST IN } \\
\text { LEARNING } \\
\text { ISLAM RELIGION } \\
\text { SUBJECT }\end{array}$ & $\begin{array}{l}\text { LEARNING } \\
\text { STYLE }\end{array}$ \\
\hline & & & & \\
\hline
\end{tabular}

Referring to the categorization of students' characteristics based on the table above, 28 students could be divided into three categories namely independent student group, guided student group, and frustrated student group. There were 4 independent students, 21 guided students, and 3 frustrated students.

The next training for trainer session was delivering knowledge about DI implementation on the aspects of teacher-based method. The approval between researchers yielded the theme of Kisah Keteladanan Wali Songo or Role Model Stories of the Nine Guardians. This theme contains four core competencies and three basic competencies. Teachers were trained to modify indicators, learning methods or activities, learning sources, time allocation, media, and evaluation. Core competency and basic competency followed the predetermined rules in guidance book. The followings were the preset curriculum modifications.

1. Modifying basic competence which was translated into indicators. 
The basis of modification on basic competency is based on bloom taxonomy ${ }^{28}$. Researchers modified the basic competency to embrace the class diversity. There were three slow learners so that basic competence needed to be adjusted to students' condition. Modification on indicator aspect is presented as follow:

\section{Table of Modifying Basic Competence}

\section{BASIC COMPETENCY \\ MODIFIED BASIC COMPETENCY}

Believing the faith of Wali

Songo towards Allah
Knowing that Wali Songo is Allah's messengers to spread Islam in Java island.

Knowing who Wali Songo are and where they come from.

\begin{tabular}{|c|c|}
\hline $\begin{array}{l}\text { Showing care and humility as } \\
\text { an implementation of Wali } \\
\text { Songo role model stories. }\end{array}$ & $\begin{array}{l}\text { Figuring out forms of generous deeds by Wali Songo. } \\
\text { Understanding the meaning of the generous deeds by } \\
\text { Wali Songo. } \\
\text { Explaining the benefits of being generous by Wali } \\
\text { Songo. }\end{array}$ \\
\hline $\begin{array}{l}\text { Understanding the role } \\
\text { model stories of Wali Songo }\end{array}$ & $\begin{array}{l}\text { Reading the stories of Wali Songo. } \\
\text { Identifying the characteristics of Wali Songo's journey. }\end{array}$ \\
\hline $\begin{array}{l}\text { Retelling the role model } \\
\text { stories of Wali Songo }\end{array}$ & $\begin{array}{l}\text { Knowing the characteristics of Wali Songo's stories } \\
\text { and being able to distinguish the story of each Wali } \\
\text { Songo. }\end{array}$ \\
\hline
\end{tabular}

\section{Modifying learning method}

Based on the modified basic competency, the learning method which was going to be performed was cooperative learning method. It was cooperative STAD learning method. This method was chosen as it has ever been employed by Aziz, Sugiman \& Prabowo ${ }^{29}$ for slow learners and it was proven to improve slow learners' learning motivation.

Steps in cooperative STAD learning method were: 1 . Teach, means presenting learning materials; 2 . Team study, consists of four or five students composed on preparation session to implement STAD learning method. Students learned the materials together in their groups; 3. Test, in which students were individually tested through quiz; 4. Team recognition, in which group score was based on each group member's score and the student with the highest score would receive gifts.

\section{Modifying learning sources}

Learning sources in DI implementation are not only teachers' handbook but also books about Wali Songo. 


\section{Modifying time allocation}

The time allocation for Wali Songo theme was two meetings modified into three meetings or $3 x$ learning hours (50 minutes). It has been decided by considering allotted time for other themes.

5. Modifying learning media and tools

The implementation of DI-based learning modification utilized map of Java island, sugar paper, and stationary to utilize three-dimension property.

6. Modifying evaluation

Evaluation could be accomplished in groups or individual. Group test was completed by circling the origins of Wali Songo. Individual test was 10 essays. Scores were divided into three classifications namely independent student group, guided student group, and frustrated student group. The following is the detail of the evaluation modification:

\section{Table of Evaluation M odification}

\begin{tabular}{|c|c|c|c|c|}
\hline \multirow[t]{2}{*}{$\begin{array}{l}\text { Type of } \\
\text { Test }\end{array}$} & \multicolumn{2}{|c|}{$\begin{array}{l}\text { Group of independent students } \\
\text { and guided students } \\
\text { ( } 25 \text { students) }\end{array}$} & \multicolumn{2}{|c|}{ Group of frustrated students } \\
\hline & $\begin{array}{l}\text { Score of each } \\
\text { number }\end{array}$ & $\begin{array}{l}\text { Range of } \\
\text { Score }\end{array}$ & $\begin{array}{l}\text { Score } \\
\text { of each number }\end{array}$ & $\begin{array}{l}\text { Range } \\
\text { of Score }\end{array}$ \\
\hline $\begin{array}{l}\text { Individual } \\
\text { essay test }\end{array}$ & $\begin{array}{l}\text { Score of } 10 \text { for } \\
\text { each number }\end{array}$ & $10-100$ & $\begin{array}{l}\text { Score of } 15 \text { for } \\
\text { each number. } \\
\text { The maximum } \\
\text { traget was } 7 \\
\text { questions. }\end{array}$ & $15-105$ \\
\hline
\end{tabular}

\section{B. Research}

Research was completed within five times face-to-face meetings in grade IV classroom during the Islamic education learning. Differentiated instruction method was implemented on April 2019. The teacher was obliged to deliver materials according to training of trainer result completed before. Researchers had collected scores from teachers. The scores on Islam religion subject were used as pretest reference for three students indicated as slow learners. The scores are described as follow:

The activity on the first meeting was giving explanation on brief history of Wali Songo. This applied new cooperative STAD teaching phase. Students were divided into nine groups according to the nine guardians (wali). The names of the groups were each name of the guardian. Each group consisted of various students from all types of students. 27 stu- 
dents were present while another one was absent. All slow learners were there. The activity on the first day of the research was giving each student one clue about the history of a guardian. They would be in the same group if their clue inferred to the same guardian. The teacher and researchers had set it up so that each group consisted of variety of students. Next, the teacher explained the history of the guardians. All students were asked to read the history of Wali Songo from the books they brought. Special observation was carried out to the three slow learners called as A, $B$, and C. Student A participated in the group, but it only happened for a short period of time. For the rest, he seemed to be daydreaming. The teacher tried to ask each student in each group to support each other. Student $B$ tended to be quiet and passive. On the first day, he did not utter a word in the group. The teacher involved student $B$ by asking something trivial but he could not provide an answer. Student $C$ seemed to be more cheerful and verbally active.

The activities on the second meeting were team study phase. It targeted at enabling students to learn more deeply about good traits of the guardians. 25 students were present on the second meeting. One of slow learners did not come to school (Student A). The first step on the day was researchers shared a map of Java. Every group circled the places where the guardians came from and spread Islam. All groups were then required to formulate questions according to the name of their group (one of the guardians). The teacher demanded all students to have a discussion in every group. Students B looked inactive. The group chief where B became the member in asked student $B$ to read the book and chose questions. However, this student did not contribute in formulating questions. Student $\mathrm{C}$ was cheerful and active in his group. Referring to the observation, student $C$ was spotted to disturb his friends in his group.

Activities on the third meeting were test and team recognition phase. The number of students present on the day was 25 . One of the slow learners was absent. Prior to the test, the teacher gave 30 minutes for students to re-read materials about Wali Songo. The teacher motivated students to help each other during test preparation. Test was administered individually. The teacher reminded that there would be the best team with the highest mean score. During the test preparation, teacher let students ask. After the phase was done, the test started. The test consisted of short answer essay consisting of 10 questions. Researchers im- 
mediately checked students' answers. One of the winners was Sunan Giri team. Its mean was 90 . The score for Student A was 70 and for Student C was 60 .

\section{Discussion}

This research reveals that slow learners improved their achievement score on Islam religion subject through daily examination. Initially, there were three slow learners as the research respondents. However, only one student managed to complete all series in this study. Two slow learners were absent with no obvious reasons. Based on the interview with the teacher of Islam religion subject, the two slow learners (Student A and B) did not come to class several times with no permission. Qualitative analysis could be carried out for the student who took a part in the experiment from the very beginning to the final step. It meant only Student $C$ was qualified to do so. Student $C$ achieved pretest score of 50 and posttest score of 60 . Pretest score turned out to be 90 after it was adjusted to the modified evaluation calculation. Researchers ran Wilcoxon test and it yielded 0,000 . Sig value of 0,000 means that there was a significant increase between pretest and posttest of Student $C$.

Modification of curriculum using DI method causes teachers to pay more attention to students with special needs in the class. Teachers know how to assess students so that curriculum is made appropriate to students' diversity in class $^{30}$. Learning objectives as well as the evaluation are adjusted to students' condition. Students should be feeling comfortable in attending the class. Based on the observation, two students were still passive while another student began to be active at keeping up with the class learning process.

DI is implemented through modification towards the curriculum employed by teachers. A class only has one curriculum called as whole curriculum. In a research conducted by Krihnakumar, Geeta $\&$ Palat ${ }^{31}$, they found out that individual approach curriculum could encourage the development of slow learners significantly. Slow learners could improve their self-esteem after being involved in learning with individual approach. On the contrary, that idea was rejected by Sebba, Byers $\&$ Rose ${ }^{32}$ who declared that slow learners who were given individual learning treatment could reduce the opportunities to be involved in team study. Field condition also showed that slow learners were assisted by their team mate in 
accomplishing the learning tasks. Referring to cooperative learning theory, it is called as positive interdependence among group members. When the teacher assigned reading task, Student A, B, and C depicted low motivation. The teacher and students on other groups motivated those students to be willing to read. There was even no idea coming up from the students when they were demanded to find idea for formulating questions. According to Cooter $\&$ Cooter J $\mathrm{r}^{33}$, slow learners did not have interest in reading and retrieved low reading comprehension ability.

Student A came from a middle to low class family. Student A was absent due to the less harmonious family condition. One cause of slow learner is economy condition. Hallan and Kauffman ${ }^{34}$ stated that one factor affecting slow learners was under-average economy condition.

Evaluation was completed by the researcher by dividing the 28 students into 9 groups. One group consisted of three students. One of characteristics of cooperative learning is the existence of positive interdependence. The ideal state for strengthening the positive interdependence is four up to five groups ${ }^{35}$.

Curriculum development for students with special needs causes narrowing of the curriculum especially on the focus of the targeted goal ${ }^{36}$. Curriculum modification which has been completed is making learning objectives to be more focused to enable frustrated students to meet these objectives.

\section{CONCLUSION}

The conclusion of this study is that curriculum modification succeeds to significantly increase pretest scores to posttest scores. This method can be applied sustainably for the next themes in Islam religion subject. DI method requires teachers to have decent knowledge in implementing DI on both teacher-based and student-based method. It is also necessary for teachers to conduct periodic evaluation so that slow learners can optimally participate in classroom learning process.

The application of DI in slow learner students follows three stages, firstly the student-based method is analyzing the characteristics of slow learner students and their needs. Secondly, modify the curriculum of Islamic religious education subjects from the content, process and evaluation. Thirdly is implementing the DI method through the learning process in the classroom. Fourthly is follow-up activities. The activity of modifying 
the curriculum is highly recommended for islamic education learning with a variety of mental conditions student. Implementers of curriculum modification need to discuss with developmental psychologists regarding the characteristics and needs of students with special needs.

\section{ENDNOTES}

1 Fitriyani, A . L. (2013). E fektifitas Remedial Teaching PA I dalam M eningkatkan $\mathrm{H}$ asil Belajar Siswa: Studi Kuasi Eksperimen pada Bahasan Sholat untuk Siswa K elas V III di SM P N egeri 3 Lembang TA 2012/2013. Bandung: Fakulras Pendidikan IImu Sosial U niversitas Pendidikan Indonesia.

2 Tafsir. (2010). Filsafat Pendidikan Islami. Bandung: Remaja Rosdakarya.

3 A isah, A. (2018). Laporan Wawancara Tentang Inklusi di SD Tumbuh. Yogyakarta: Fakultas A gama I slam U niversitas.

4 Susan, J.Ko. (2018). C reating Trauma Information system: Child Welfare, Education First. Responden $\mathrm{H}$ ealth $\mathrm{C}$ are. Profesional Psycology: Research and Practice. Vol 29, No 4, 396-402. DOI 10370735 - 7028.39.4.396

5 A melia, W. (2016, D esember). Karakteristik dan Kesulitan A nak Belajar Slow Learner. A isyah: Jurnal IImu K esehatan, 1(2), 53-58.

6 Pramuji, E. (2015). M etode Pembelajaran PA I di SD N egeri Tanjung 1 K ecamatan Purwokerto Selatan K abupaten Banyumas TA 2014/ 2015. Purwokerto: Program Studi PAI Fakultas Tarbiyah dan IImuKeguruan IAIN Purwokerto.

7 H anum, L. (2014, D esember). Pembelajaran PAI Bagi Aanak Berkebutuhan Khusus. Jurnal Pendidikan A gama Islam, XI(2), 50-62.

8 H anum, L. (2014, D esember). Pembelajaran PAI Bagi Aanak Berkebutuhan Khusus. Jurnal Pendidikan A gama Islam, X I(2), 50-62

9 N ugrahayati, W., \& M ustadi, A. (2019). Slow Learner LearningFactsin Their Inclusion Class. 6th International C onference on E ducational Reserach and Innovation (ICERI 2018) (pp. 149-152). A tlantis Press.

10 Tomlinson, C. A., \& M cT ighe, J. (2006). Integrated D ifferentiated Instruction and $U$ nderstanding by $D$ esign. A lexander V irginia: Assosiation for Supervision and Curriculum D evelopment.

11 D'A mico, \& Kate, G. (2010). Differentiated Instruction for M iddle School Science Teacher A ctivities and Strategies for Inclusive C lassroom. San Fransisco: John W iley $\&$ Sons, Inc.

12 Tomlinson, C. A., Brighton, C., H ertberg, H., Callahan, C. M ., M oon, T. R., Brimijpon, K., et al. (2003). Differentiating Instruction in Response to Student Readiness, Interest and Learning Profile in A cademically Diverse C lassrooms. Journal for the E ducation of the $G$ ifted, 119-105.

13 G hergut, A. (2011). Education of C hiildren W ith Special N eeds in Romania; Attitudes and Experiences. Precedi-Social and Behavioral Sciences, 595-599.

14 G eorge, P. S. 2005. A rationale for differentiating instruction in the regular classroom. Theory into practice, 44(3), 185-193.

15 H all, T. (2002). D ifferentiated Instruction. Wakefield: M A C entre O n. 
D 'A mico, \& Kate, G . (2010). D ifferentiated Instruction for M iddleSchool Science Teacher A ctivities and Strategies for InclusiveC lassroom. San Fransisco: John W iley $\&$ Sons, Inc.

17 H eacox, D. (2002). D ifferentiating Instruction in The Regular C lassroom. U SA: Free Spirit Publising.

18 Andini, D. W. (2016, M ei). D ifferentiated Instruction: Solusi Pembelajaran dalam Keberagaman Siswa di Kelas Inklusif. Trihayu: Jurnal Pendidikan keSD an, 2, 340-349.

19 Tomlinson, C. A., Brighton, C., H ertberg, H., Callahan, C. M., M oon, T. R., Brimijpon, K., et al. (2003). Differentiating Instruction in Response to Student Readiness, Interest and Learning Profile in A cademically Diverse C lassrooms. Journal for the Education of the $G$ ifted, 119-105.

20 Tomlinson, C. A., Brighton, C., H ertberg, H., Callahan, C. M ., M oon, T. R., Brimijpon, K., et al. (2003). Differentiating Instruction in Response to Student R eadiness, Interest and Learning Profile in A cademically Diverse C lassrooms. Journal for the E ducation of the $G$ ifted, 119-105.

21 Tomlinson, C. A ., Brighton, C., H ertberg, H., Callahan, C. M ., M oon, T. R., Brimijpon, K., et al. (2003). Differentiating Instruction in Response to Student R eadiness, Interest and Learning Profile in A cademically Diverse C lassrooms. Journal for the E ducation of the $G$ ifted, 119-105.

22 M uhaimin. (2005). Pengembangan K urikulum Pendidikan A gama I slam di Sekolah, M adrasah dan Perguruan. Jakarta: Raja G rafindo Persada.

23 Latipun. (2011). Psikologi Eksperimen. Malang: U niversitas M uhammadiyah $M$ alang Press.

24 Walgito, B. (2010). Pengantar Psikologi U mum. Yogyakarta: Penerbit Andi.

25 Silalahi, U. (2015). M etode Penelitian Sosial Kuantitatif. Bandung: Refika A ditama.

26 Silalahi, U. (2015). M etode Penelitian Sosial K uantitatif. Bandung: Refika A ditama.

27 Tomlinson, C. A., Brighton, C., H ertberg, H., Callahan, C. M., M oon, T. R., Brimijpon, K., et al. (2003). Differentiating Instruction in Response to Student Readiness, Interest and Learning Profile in A cademically Diverse C lassrooms. Journal for the Education of the G ifted, 119-105.

28 A dams, N. (2015). Bloom's Taxonomy of C ognitive L earning O bjectives. Journal of the M edical Library A ssosiation, 152.

29 A żz, A. N., Sugiman, S., \& Prabowo, A . (2016). A nalisis Proses Pembelajaran $M$ atematika pada Anak Berkebutuhan Khusus (ABK) Slow Learner di Kelas Inklusif. K reano, Jurnal M atematika K reatif-.novatif, 111-120.

30 H eacox, D. (2002). D ifferentiating Instruction in The Regular C lassroom. U SA: Free Spirit Publising.

31 Krishnakumar, P., G eeta, M ., \& Palat, R. (2006). Effectiveness of I ndividualized Education Program For Slow Learners. Indian Journal of Pediatrics, 73 (2), 135-137.

32 Sebba, J., Byers, R., \& Rose, R. (2019). Redefining The W hole C urriculum for 
Pupils with L earning D ifficulties. London: R outledge, Taylor \& Francis G roup.

33 C ooter, K. S., \& C ooter Jr, R. B. (2004). O ne Size doesnot fit all: Slow Learners in the Reading C lassroom. The Reading Teacher, 57-80.

34 H allahan, D. P., \& Kauffman, J. M. (1988). Exceptional C hildren: Introduction to Special Education. N ew Jersy: Prentice Hall, Inc.

35 Lim, T. L., Shahrill, M., M undia, L., Tengah, K. A., Tan, A., \& M ahadi, M. A . (2016). An alternative approach to teaching: Implementing a cooperative learning strategy STAD at the junir college level. A dvanced Science L etters, 17251729.

36 Sebba, J., Byers, R ., \& Rose, R. (2019). Redefining The W hole C urriculum for Pupils with L earning D ifficulties. London: Routledge, Taylor \& Francis G roup. 
